\title{
Characterization of methicillin susceptible and methicillin-resistant Staphylococcus aureus from healthy cattle and buffaloes in a linked community
}

\author{
Thoraya Saad, Adel El-Gohary, Amro Mohamed, Mayada Gwida* \\ Department of Hygiene and Zoonoses, Faculty of Veterinary Medicine, Mansoura University, Mansoura 35516, Egypt
}

\section{ARTICLE HISTORY}

Received: 19.05 .2021

Revised: 01.06.2021

Accepted: 03.06.2021

Correspondence to Mayada Gwida; Tel: 00201003783173; E-mail:

Mayada_gwida@mans.edu.eg; ORCID: 0000-0001-6312-4703

\section{ABSTRACT}

\begin{abstract}
Objective: To give updated information regarding the occurrence of methicillin-susceptible and methicillin-resistant $S$. aureus isolated from dairy cattle and buffalos in a linked study population. Design: Descriptive study.

Samples: The study comprised 360 samples (240 of animal origin and 120 from humans). Three different types of samples (including teat swabs, milk and feces, 80 each) were collected from animals in addition (nasal swabs, hand swabs and stool specimens, 40 each) were collected from contact persons.

Procedures: The collected samples were examined by stander techniques.

Results: S. aureus was identified in 59.3\% (73/123) from the examined farm dairy cattle. MRSA was not determined in any of the examined cows' samples while for buffaloes, it was detected in $63.2 \%(12 / 19)$, $64.7 \%(11 / 17)$ and $40 \%(4 / 10)$ in milk, teat swabs and fecal samples, respectively. For smallholding cattle and buffaloes, MRSA was detected in the above mentioned samples and in relation to the recovered $S$. aureus isolates (at cefoxitin $4 \mu \mathrm{g} / \mathrm{ml}$ ) in the following pattern: $22.2 \%(4 / 18), 15 \%(3 / 20)$ and $18.8 \%(3 / 16)$ and $20 \%(3 / 15), 100 \%(11 / 11)$ and $43.8 \%(7 / 16)$, respectively. However, in contact persons the percentage was $85(34 / 40), 82.5(33 / 40)$ and $90(36 / 40)$ from nasal swabs, hand swabs and stool specimens, respectively.

Conclusion and clinical relevance: The results herein confirmed that cows, buffaloes and their contact workers could play a significant role in the transmission of MRSA, whereas the detection of MRSA in the raw milk, teat swabs and feces of cows and buffaloes may create the opportunity for the transmission of such bacteria.
\end{abstract}

Keywords: S. aureus; MRSA; Cattle; Buffalo; linked study

The resistance of $S$. aureus to antimicrobials remains a

\section{INTRODUCTION}

Staphylococcus aureus (S. aureus) is a ubiquitous zoonotic pathogen with clinical relevance for both humans and animals [1-2]. The bacterium is a common colonizer and is considered a part of the natural commensal flora of humans and animals and colonizing approximately $30-50 \%$ of human population [3]. It can cause either minor infections in humans such as superficial skin and soft tissue infections or life-threatening conditions including necrotizing fasciitis, pneumonia, septicemia, food poisoning, postoperative wound infections, and nosocomial infections [4].

S. aureus has received a special interest in animal since they are considered a major pathogen of mastitis in dairy cattle and buffaloes [1,5].Its ability to cause a multitude of infections is probably due to the expression of various toxins, virulence factors, as well as cell wall adhesion proteins [2]. On the other side, its low cure rate and the ability of the organism to persist in the mammary gland in the form of undetected subclinical infections as well as its resistance to antibacterial therapies make it a unique pathogen that necessitate continuous monitoring $[\mathbf{1 , 6}]$. global setback and can complicate the treatment of infections especially in both resource-limited and developed countries [7].The resistance of the bacterium to the used antibacterial agents is a serious problem and is strongly related to the improper and excessive use of antimicrobials either for the treatment of animal ailments or as growth promoters in food producing animals.

Methicillin -resistant $S$. aureus, which initially emerged as human nosocomial infections, has also spread in dairy animals in different countries [8]. It has been reported that the acquisition of the mecA gene is the cause of resistance to methicillin. This gene encodes an alternative penicillin-binding protein, called PBP2A that exhibits a low affinity for betalactam antibiotics [9]. The existence of MRSA strains in the environment could be a possible source of MRSA infection in dairy farms, because they can survive for several months in the surrounding environment [10].

The epidemiology of MRSA has changed due to the increasing appearance of livestock-associated MRSA (LAMRSA), which has been detected in food producing animals and workers who in close contact with MRSA colonized animals [11]. In Egypt, there has been limited information regarding the existence of MRSA strains in cows and buffaloes 
as well as their contact workers in a linked community. Hence, the present study was set to fill in the gap and provide updated information regarding the occurrence of methicillinsusceptible and methicillin- resistant $S$. aureus isolates in a linked study population including commercial and small holding cattle and buffaloes as well as their contact owners.

\section{MATERIAL AND METHODS}

\subsection{Samples collection and preparation}

The study was performed during the period from December 2019 till October 2020 and comprised 360 samples (240 from animal origin and 120 from humans). Samples of animal origin ( $n=240$ ) were collected from seemingly healthy cattle $(n=40)$ and buffalo cows $(n=40)$ that were raised at Dakahlia and Damietta governorates in different geographic locations. From each animal, three different types of samples (including teat swabs, milk and feces) were collected. The cows were dairy animals and were either reared as smallholders (22 cattle; 17 buffalo) or belonged to commercial farms (18 cattle; 23 buffalo). On the other side, samples of human origin ( $n=40$ ) included nasal swabs, hand swabs and stool specimens, 40 each were collected from contact keepers. The study was performed in accordance with the ethical committee of Mansoura University and follows the guidelines for the Care and Use of Agricultural Animals in Research and Teaching, $3^{\text {rd }}$ ed. (http://www.fass.org/). The investigated animals were selected based on convenience and a consent to participate in sampling procedure was obtained from the contact owners. For more clarity, the detailed information about the sampling and processing for each type of sample were given below.

\subsection{Isolation and Identification of S. aureus}

The collected samples were inoculated into tryptone soya broth (TSB) with $70 \mathrm{mg}$ of $\mathrm{NaCl} / \mathrm{ml}$ and were incubated at $37^{\circ} \mathrm{C}$ for $24 \mathrm{hrs}$. After incubation, a loopful (i.e. approximately $10 \mu \mathrm{L}$ ) from each of the incubated broth was streaked onto selective media for $S$. aureus, Baird Parker agar base (Oxoid, CM 275) supplemented with $5 \%$ egg yolk potassium tellurite and were incubated at $37^{\circ} \mathrm{C}$ for $24-48 \mathrm{hr}$ [1].Colonies with typical growth of staphylococci (i.e. black, shiny, convex colonies) were picked up and streaked on Baired Parker agar for purification and incubated at $37^{\circ} \mathrm{C}$ for $48 \mathrm{hrs}$. The cultivated colonies were checked for purity and confirmed as Staphylococcus spp. using biochemical tests (i.e. coagulase test, catalase test and mannitol fermentation test). The selective purified colonies were finally preserved as glycerol stock at $-20^{\circ} \mathrm{C}$ for further identification.

\subsection{Detection of methicillin-resistant S. aureus (MRSA)}

The biochemically identified $S$. aureus strains were cultured on mannitol salt agar plates containing cefoxitin at two different concentrations $(2 \mu \mathrm{g}$ and $4 \mu \mathrm{g} / \mathrm{ml})$. The growing colonies were tentatively considered as MRSA and were kept in glycerol at $-20^{\circ} \mathrm{Cfor}$ further investigations[12]. Strains were classified as MRSA if they grow in parallel at both cefoxitin concentrations.

\subsection{Molecular Characterization of MRSA strains}

All biochemically suspected MRSA isolates were substantially examined by PCR for nuc and the positive samples were further tested for mecA gene.

\subsubsection{DNA extraction}

Bacterial lysates were obtained by the method previously mentioned by [13]. Three to five colonies of purified biochemically suspected MRSA strains were picked up and transferred to a sterilized tube containing $100 \mu \mathrm{l}$ of sterilized distilled water, then heated for 15 minutes at $95^{\circ} \mathrm{C}$ in heat block. The boiled lysates were then centrifuged at $13000 \mathrm{rpm}$ for 10 minutes. The supernatants were transferred to sterile Eppendorf tubes, kept at $-20^{\circ} \mathrm{C}$, and used as DNA templates.

\subsubsection{Method of DNA amplification}

The polymerase chain reaction (PCR) assays were performed in individual reactions using an applied Biosystems 96-well Thermal Cycler to detect (nuc and mecA). The sets of primer sequences and corresponding amplicon sizes are showed in Table 1. PCR reactions were performed in a total volume of $20 \mu \mathrm{L}$ consisting of $10 \mu \mathrm{L}$ of $2 X$ Red master Mix (Applied Biotechnology Co., Egypt), $3 \mu \mathrm{L}$ DNA templates, and 1 $\mu \mathrm{L}$ of each primer and completed to $20 \mu \mathrm{l}$ with DNA/RNA free water. PCR reactions and thermal conditions used were performed, according to Sallam et al [14], with an initial denaturation at $94^{\circ} \mathrm{C}$ for $2 \mathrm{~min}, 35$ cycles were performed (98 ${ }^{\circ} \mathrm{C}$ for 10 seconds, $58{ }^{\circ} \mathrm{C}$ for 30 second and $68^{\circ} \mathrm{C}$ for $1 \mathrm{~min}$ ), and final extension at $68^{\circ} \mathrm{C}$ for $7 \mathrm{~min}$. An aliquot of each amplified PCR product was electrophoresed in ethidium bromide stained $1.5 \%$ agarose gel for 30 minutes at $100 \mathrm{~V}$ then visualized and photographed by an ultraviolet transilluminator.

\subsection{Antibiotic resistance profiles in MRSA strains}

The susceptibility to cefoxitin $(30 \mu \mathrm{g})$, penicillin $\mathrm{G}(10$ units), clindamycin $(2 \mu \mathrm{g})$, gentamycin $(10 \mu \mathrm{g})$, kanamycin (30 $\mu \mathrm{g})$, sulphamethoxazol $(1.25 / 23.75 \mu \mathrm{g})$, ciprofloxacin $(5 \mu \mathrm{g})$, chloramphenicol $(30 \mu \mathrm{g})$, vancomycin $(30 \mu \mathrm{g})$ and fusidic acid (5-10 $\mu \mathrm{g})$ was determined by the disk diffusion method as described in Clinical and Laboratory Standards Institute guidelines [15].

\section{Results and Discussion}

In Egypt, there are two different production systems: the first one is an efficient, and specialized commercial dairy farms, while the second is smallholders which keep buffaloes, cows, or both in a small-scale production. Given that milk and dairy products are an essential part of food in Egypt, diseases in dairy animals that are caused by bacterial pathogens 
including $S$. aureus can not only affect milk production but also pose a potential health hazard [1]. In the present study, $S$. aureus was identified in $59.3 \%$ (73/123) from the examined farm dairy animal samples; whereas it was recovered from all milk samples (18/18), 50\% (9/18) teat swab but not determined in fecal samples of dairy cows. The findings regarding the occurrence of $S$. aureus in cow's milk was higher than those reported by other researchers [5, 16-17] who found the following contamination rate in milk samples (6.39\%; $36.3 \%$ and $72.8 \%)$. In addition, the recovery rate of $S$. aureus in teat swabs was nearly similar to that given by ELGohary and others [16] who detected S. aureus in 159 out of $372(42.7 \%)$ from farm cows teat swabs. While in the present study $S$. aureus did not recover from any of farm cows' fecal samples. In another study, S. aureus was detected in one sample out of $40(2.5 \%)$ fecal samples of farm cows [18]. On the other side, the overall occurrence of $S$. aureus in the examined farm buffalos' samples was $66.75 \%$ (46/69) and the recovery rate in the examined milk samples, teat swabs and feces were $82.6 \%(19 / 23), 73.9 \%$ (17/23) and $43.5 \%(10 / 23)$, respectively. MRSA was identified in the previously examined samples (at $2 \mu \mathrm{g} / \mathrm{ml}$ cefoxitin) with the percentage of 66.7 $(12 / 18)$ and $11.1 \%(1 / 9)$ in milk and teat swabs, respectively but was not detected in any of the examined fecal samples. In addition, MRSA was not determined in any of the examined cows' samples when using cefoxitin at a concentration $4 \mu \mathrm{g} / \mathrm{ml}$ but for buffaloes samples, MRSA was determined at the concentration of $2 \mu \mathrm{g} / \mathrm{ml}$ of cefoxitin in $63.2 \%$ (12/19), $64.7 \%$ $(11 / 17)$ and $40 \%(4 / 10)$ in milk samples, teat swabs and feces, respectively; while at the concentration of $4 \mu \mathrm{g} / \mathrm{ml}$ it was $10.5 \%(2 / 19), 41.2 \%(7 / 17)$ and $30 \%(3 / 10)$. S. aureus was detected recently in Egypt in 31 out of 88 (35.2\%) mastitic milk samples of farm buffaloes [17]. The distribution of MRSA in milk samples of farm cows was in harmony with that previously reported by Huber and others [19] who failed to identify MRSA in bulk tank milk and raw milk cheese but reported MRSA in $1.4 \%(2 / 142)$ of mastitic cow's milk. In different studies from Egypt, the occurrence of MRSA in milk of farm cows was $41 \%(111 / 271)$ and $37.7 \%(20 / 53)[16,17]$, respectively. While MRSA was not detected in teat swabs of farm cows using cefoxitin with concentration $4 \mu \mathrm{g}$ as showed in Table 2. Similar result was detected by Lim and their colleagues [10] who failed to determine MRSA in teat swabs of farm cows. On the other hand, MRSA was not detected in feces of farm cows using cefoxitin at concentration of $2 \mu \mathrm{g}$ and $4 \mu \mathrm{g}$ (Table 2).Similar result was detected by Lim et al.[18]who failed to detect MRSA in feces of farm cows.

The high detection rate of $S$. aureus from the cow's milk could be attributed to existence of several sources of contamination such as unclean utensils, towels and unclean milkers' hands. It might also be attributed to improper housing, bad handling of animals and bad sanitation [17] as well as contaminated surfaces including stainless steel, aluminum and glass which act as reservoir for $S$. aureus in dairy environment. Also $S$. aureus can get access to the milk either by direct excretion from infected udders, or via environmental contamination during the handling and processing of raw milk. Likewise, the relaxation of sphincter muscles of teats in older animals could also enable the bacterium to reach udder.

For smallholder animals, $S$. aureus was identified in $96 / 117$ with the percentage of $82 \%$ in the examined cows' samples and the recovery rate was $81.8 \%(18 / 22)$ in milk samples. Low detection rate $(41.6 \% ; 3.7 \% ; 7.6 \%)$ was reported in several studies in Egypt $[\mathbf{2 0}, \mathbf{5}, \mathbf{1}]$. Similar pattern of occurrence was given by Kotb and Sayed [21] who isolated $S$. aureus with the percentage of (100) $5 / 5$ from milk samples of smallholder mastitic cows and in $14 / 25$ (56\%) milk samples of smallholder healthy cows. While, the occurrence of $S$. aureus in fecal samples of smallholder cows was $72.7 \%$ $(16 / 22)$, which is higher than that reported by EL-Gohary et al. [20] who reported that the occurrence of $S$. aureus in fecal samples of smallholder cows was $21.3 \%$ (16/75).

The occurrence of $S$. aureus in milk samples of smallholder buffaloes $(15 / 17,88.2 \%)$ was higher than the results obtained by other researchers in Egypt either from healthy animals or from those with mastitis. For example, in 2015 El-Ashker et al. [5], and Elhaig and Selim [22] detected S. aureus with the percentage of 8.3 and 36.3 in smallholder buffaloes with mastitis, respectively. $S$. aureus was also detected in 16/17 (94.1\%) fecal samples of smallholder buffaloes which is higher than those reported by EL-Gohary et al.[20] who isolated $S$. aureus with the percentage of13.3 $(8 / 60)$ in fecal samples.

MRSA was detected among the recovered $S$. aureus isolates (using cefoxitin at concentration of $2 \mu \mathrm{g} / \mathrm{ml}$ ) in $27.8 \%$ (5/18), 90\% (18/20) and 56.3\% (9/16) in smallholders cows' milk, teat swabs and feces, respectively. While, it was $22.2 \%$ $(4 / 18), 15 \%(3 / 20)$ and $18.8 \%(3 / 16)$ in the former samples at $4 \mu \mathrm{g} / \mathrm{ml}$ cefoxitin. In buffaloes, $S$. aureus was determined in $88.2 \%(15 / 17), 64.2 \%(11 / 17)$ and $94.1 \%(16 / 17)$ in the abovementioned samples, respectively. By using $2 \mu \mathrm{g} / \mathrm{ml}$ cefoxitin, MRSA was detected in $20 \%(3 / 15), 100 \%(11 / 11)$ and $43.8 \%$ $(7 / 16)$ in milk samples, teat swabs and feces, respectively; while at the concentration of $4 \mu \mathrm{g} / \mathrm{ml}$ cefoxitin it was $6.7 \%$ (1/15), 9.1\% (1/11) and 12.5\% (2/16) (Table3). The distribution of MRSA in smallholder cow's milk was in harmony with that previously reported in Egypt by El-Ashker et al.[1] who identified MRSA in milk samples with the percentage of (28.6) 12/42. In another study in Egypt, [21] reported higher detection rates of MRSA in milk samples (36\%) 9/25 from healthy cows and (80\%) $4 / 5$ from mastitis cow's milk samples. While the distribution of MRSA in milk samples of smallholder buffaloes was lower than the result obtained in Egypt by Kotb and Sayed [21] who identified MRSA with a percentage of 16.6 (5/30) from milk samples which obtained from healthy buffaloes and in $37.5 \%$ (3/8) from mastitis buffaloes milk 
samples. It is difficult to compare the obtained results with other studies in the context of $S$. aureus and MRSA occurrence in buffalo's teat swabs and feces due to the lack of studies related to these issues. Taken altogether, it has been suggested that the discrepancies of our detection rates of $S$. aureus from other similar studies could be attributed to many factors including the number of collected samples from each category of animal, seasons and localities. In addition, it becomes clear that $S$. aureus can be found in high percentage and this could be attributed to poor hygiene and bad farm management [23]. Regarding the high detection rate of MRSA, Algammal et al. mentioned that the uncontrolled use of antibiotics in Egypt to treat mastitis leads to the emergence of MRSA and the widespread of multi drug resistance $S$. aureus in bovine species to different $\beta$-lactam compounds [17].

Table 1. Oligonucleotide primers sequences used for amplification of S. aureus strains.

\begin{tabular}{llll} 
Primer & Primer sequence & Amplicon size (bp) & Reference \\
\multirow{2}{*}{ Nuc } & F: 5'-GTGCTGGCATATGTATGGCAATTG-'3 & 660 & \\
& R: 5' -CTGAATCAGCGTTGTCTTCGCTCCAA-'3 & & Sallam et al. (2015) \\
mecA & F: 5'-GATTGGGATCATAGCGTCA-'3 & 1200 & \\
& R: 5'-CAGTATTTCACCTTGTCCG-'3 & &
\end{tabular}

Table 2. Frequency distribution of $S$. aureus and MRSA in farm animals.

\begin{tabular}{|c|c|c|c|c|c|c|c|c|}
\hline \multirow[t]{2}{*}{ Species } & \multirow[t]{2}{*}{ Type of samples } & \multirow[t]{2}{*}{ No. of samples } & \multicolumn{2}{|c|}{ S. aureus } & \multicolumn{2}{|c|}{$\begin{array}{l}\text { MRSA } \\
\text { Cefoxitin } 2 \mu \mathrm{g}\end{array}$} & \multicolumn{2}{|c|}{$\begin{array}{l}\text { MRSA } \\
\text { Cefoxitin } 4 \mu \mathrm{g}\end{array}$} \\
\hline & & & No. & $\%$ & No. & $\%$ & No. & $\%$ \\
\hline \multirow[t]{4}{*}{ Cows } & Milk & 18 & 18 & 100 & 12 & 66.7 & - & - \\
\hline & Teat swabs & 18 & 9 & 50 & 1 & 11.1 & - & - \\
\hline & Feces & 18 & zero & 0 & - & - & - & - \\
\hline & Total & 54 & 27 & 50 & 13 & 48.1 & - & - \\
\hline \multirow[t]{4}{*}{ Buffaloes } & Milk & 23 & 19 & 82.6 & 12 & 63.2 & 2 & 10.5 \\
\hline & Teat swabs & 23 & 17 & 73.9 & 11 & 64.7 & 7 & 41.2 \\
\hline & Feces & 23 & 10 & 43.5 & 4 & 40 & 3 & 30 \\
\hline & Total & 69 & 46 & 66.7 & 27 & 58.7 & 12 & 26 \\
\hline Total & & 123 & 73 & 59.3 & 40 & 54.8 & 12 & 16.4 \\
\hline
\end{tabular}

Table 3. Frequency distribution of S. aureus and MRSA in smallholders' animals.

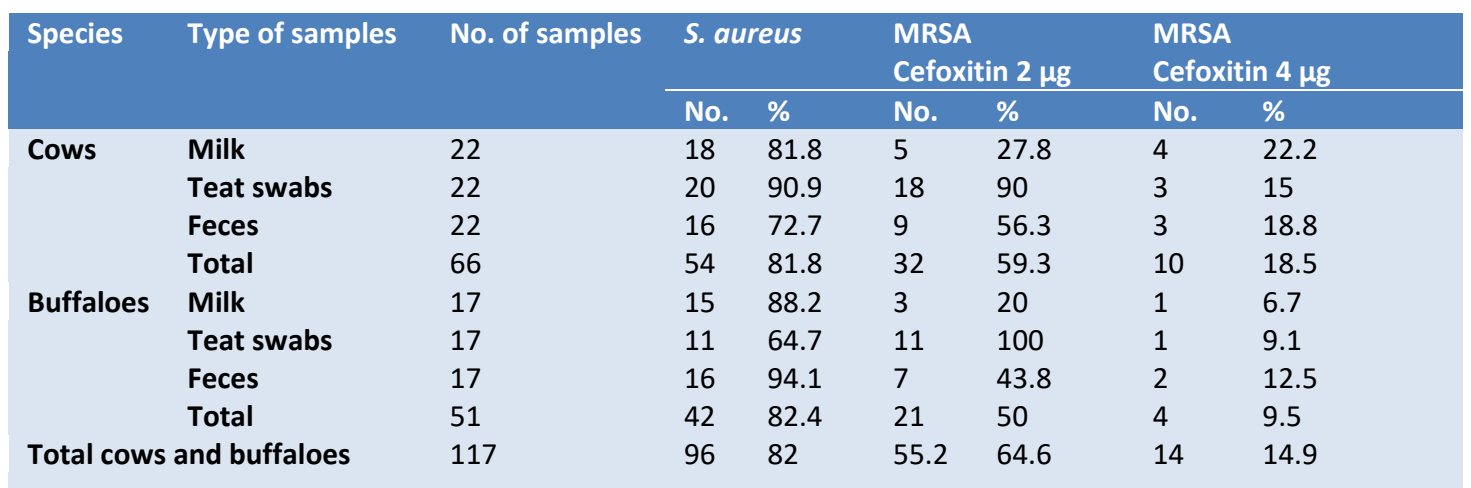

Regarding the occurrence of $S$. aureus in human samples, our findings demonstrated that $103 / 120$ (85.8\%) were recovered from the examined human samples; whereas $85 \%$ (34/40), 82.5\% (33/40) and $90 \%(36 / 40)$ were determined from nasal, hand swabs and stool specimens, respectively. In several studies in Egypt [24,22,25,16] low detection rates were reported (36.7\%) 11/30, (40\%) 20/50, (53.8\%), and (70.4\%) 19/27, respectively. However, the occurrence of $S$. aureus in human hand swabs was similar to that reported by Kamal and other researcher [26]. For stool specimens, our finding was higher than those reported previously [27;20]. The authors identified S. aureus in 20\% (5/25) and 45\% (45/100) of the examined stool specimens. For the distribution of MRSA in the examined human samples, it was identified in $35.3 \%$ $(12 / 34), 33.3 \%(11 / 33)$ and $61.1 \%(22 / 36)$ at the concentration of $2 \mu \mathrm{g} / \mathrm{ml}$ and in $20.6 \%$ (7/34), 21.2\% (7/33) and $27.8 \%$ $(10 / 36)$ at concentration $4 \mu \mathrm{g} / \mathrm{ml}$ from nasal, hand swabs and stool specimens, respectively. In Egypt, nearly similar result $(31.6 \%, 6 / 19)$ was reported from nasal swabs of dairy farm worker [16]. Nevertheless, a higher finding (40\%, 16/40) was recorded from meat handlers [28]. On the contrary, low detection rate $(7 \%, 3 / 43)$ was reported in Korea [10]. For the 
stool specimens, high recovery rate of MRSA was detected from contact workers $(44.8 \%, 26 / 58)[29]$. It becomes clear that the occurrence of MRSA in workers and animals represent great public health concern whereas theses resistant bacteria may spread to the environment causing hazards not only on health care or human health but also disseminates to food channel.

In the present study 50/360 (13.9\%) were phenotypically characterized as MRSA. However, only 28 isolates (56\%) harbored nuc gene. Out of the molecularly identified $S$. aureus strains $(n=28), 19$ isolates $(67.9 \%)$ harbored mecA gene and were confirmed as MRSA. In Egypt, a previous study carried out by El-Jakee et al.[30] the authors detected mecA gene in (57.1\%) $4 / 7$ of the examined bovine milk. Kamal et al. couldn't detect mecA gene in any of the examined hand swabs from dairy workers [26]. While AL-Ashmawy et al. found that (75\%) $30 / 40$ of dairy animals' milk samples were expressed mecA gene [31]. Ismail and others found that all 16 isolates that phenotypically confirmed as MRSA were expressed to nuc gene and mecA gene[28]

For the antibiotic susceptibility testing, table 5 demonstrated that MRSA isolates $(n=19)$ showed high resistance to penicillin $\mathrm{G}$ and cefoxitin (100\% each) followed by kanamycin (89.5\%), fusidic acid (68.4\%) and gentamicin (57.9\%).Whereas the tested MRSA strains showed susceptibility to ciprofloxacin (100\%) followed by vancomycin and clindamycin (78.9\%), sulphamethoxazol and chloramphenicol (68.4\%). These results were similar to that previously obtained in Egypt by AL-Ashmawy et al.[31] who found that MRSA isolates $(n=414)$ which obtained from raw milk and dairy products were highly resistant to penicillin, clxacillin, amoxicillin (87.9\%), (75.9\%) and (55.6\%) respectively. While showed low resistance to ciprofloxacin (15.5\%) and sulphamethoxazol (14\%).

In another study conducted by Ismail et al. the authors found that all MRSA isolates $(n=20)$ which obtained from meat handlers' swabs were sensitive to ciprofloxacin $(100 \%)$ and resistant to penicillin (100\%) and sulphamethoxazol (100\%) [28].

\section{Conclusion}

The results reported in the present study confirmed that cows, buffaloes and their contact workers could play a significant role in transmission of MRSA, whereas detection of MRSA in the raw milk, teat swabs and feces of cows and buffaloes may create the opportunity for the transmission of such bacteria. MRSA could be transmitted to cattle and buffaloes through contaminated workers. On the other hand, unwise use of antibiotics in livestock could result in the development of antimicrobial resistance in MRSA, which is a growing problem in both developed and developing countries.
Table 4. Occurrence of $S$. aureus and MRSA in contact workers.

\begin{tabular}{|c|c|c|c|c|c|c|}
\hline \multirow[t]{2}{*}{$\begin{array}{l}\text { Type of } \\
\text { Samples }\end{array}$} & \multicolumn{2}{|c|}{ S. aureus } & \multicolumn{2}{|c|}{$\begin{array}{l}\text { MRSA } \\
\text { Cefoxitin } 2 \mu \mathrm{g}\end{array}$} & \multicolumn{2}{|c|}{$\begin{array}{l}\text { MRSA } \\
\text { Cefoxitin } 4 \mu \mathrm{g}\end{array}$} \\
\hline & No. & $\%$ & No. & $\%$ & No. & $\%$ \\
\hline $\begin{array}{l}\text { Nasal swabs } \\
(n=40)\end{array}$ & 34 & 85 & 12 & 35.3 & 7 & 20.6 \\
\hline $\begin{array}{l}\text { Hand swabs } \\
(n=40)\end{array}$ & 33 & $\begin{array}{l}82 . \\
5\end{array}$ & 11 & 33.3 & 7 & 21.2 \\
\hline Stool $(n=40)$ & 36 & 90 & 22 & 61.1 & 10 & 27.8 \\
\hline Total $(n=120)$ & 103 & $\begin{array}{l}85 . \\
8\end{array}$ & 45 & 43.7 & 24 & 23.3 \\
\hline
\end{tabular}

Table 5. Antibiotic susceptibility results of MRSA strains $(n=19)$.

\begin{tabular}{lllll} 
Antimicrobial agent & S & \multicolumn{3}{l}{ R } \\
& No. & $\%$ & No. & $\%$ \\
Cefoxitin (Fox) & - & - & 19 & 100 \\
Penicillin G (p) & - & - & 19 & 100 \\
Kanamycin (K) & 2 & 10.5 & 17 & 89.5 \\
Gentamycin (CN) & 8 & 42.1 & 11 & 57.9 \\
Clindamycin (DA) & 15 & 78.9 & 4 & 21 \\
Sulfamethxacin (SXT) & 13 & 68.4 & 6 & 31.6 \\
Ciprofloxacin (CIP) & 19 & 100 & - & - \\
Chloramphenicol (C) & 13 & 68.4 & 6 & 31.6 \\
Vancomycin (VA) & 15 & 78.9 & 7 & 36.8 \\
Fusidic acid (FA) & 6 & 31.5 & 13 & 68.4
\end{tabular}

S: sensitive, R: resistant

\section{Conflict of interest}

No conflict of interest.

\section{Author contributions}

Thoraya Saad carried out the lab work, Mayada Giwda conceptualized the study, planned for the research activity, data analysis and wrote the manuscript. Adel El-Gohary and Amro Mohamed revised the final version. All authors have read and approved the final version of the manuscript for publication.

\section{REFRENCES}

[1] El-Ashker M, Gwida M, Monecke S, El-Gohary F, Ehricht R, Elsayed M, et al. Antimicrobial resistance pattern and virulence profile of $S$. Aureus isolated from household cattle and buffalo with mastitis in Egypt. Vet Microbiol Https://doi.org/10.1016/j.vetmic.2019.108535 2020;240:108535

[2] Monecke S, Müller E, Braun SD, Armengol-Porta M, Bes M, Boswihi S, et al. Characterisation of S. Aureus/MRSA CC1153 and review of mobile genetic elements carrying the fusidic acid resistance gene fusc Sci Rep 2021;11:1-13. Https://doi.org/10.1038/s41598-021-86273-4

[3] weba CC, Zishiri OT, El Zowalaty ME. Methicillin-resistant Staphylococcus aureus: livestock-associated, antimicrobial, and heavy metal resistance. Infect Drug Resist 2018;11:2497. Https://doi.org/10.2147/IDR.S175967

[4] Akinduti AP, Osiyemi JA, Banjo TT, Ejilude O, El-Ashker M, Adeyemi AG, et al. Clonal diversity and spatial dissemination of multi-antibiotics resistant 
Staphylococcus aureus pathotypes in Southwest Nigeria. Plos one 2021;16:e0247013. Https://doi.org/10.1371/journal.pone.0247013

[5] El-Ashker M, Gwida M, Tomaso H, Monecke S, Ehricht R, El-Gohary F, et al. Staphylococci in cattle and buffaloes with mastitis in Dakahlia Governorate, Egypt. Int J Dairy Sci 2015;98:7450-9. Https://doi.org/10.3168/jds.2015-9432

[6] Sears PM, mccarthy, K.K. Management and treatment of staphylococcal mastitis. Vet Clin N Am-Food A 2003. Https://doi.org/10.1016/S07490720(02)00079-8

[7] Monecke S, Kuhnert P, Hotzel H, Slickers P, Ehricht R. Microarray based study on virulence-associated genes and resistance determinants of Staphylococcus aureus isolates from cattle. Vet Microbiol 2007;125:12840. Https://doi.org/10.1016/j.vetmic.2007.05.016

[8] Köck R, Becker K, Cookson B, van Gemert-Pijnen J, Harbarth S, Kluytmans J, et al. Methicillin-resistant Staphylococcus aureus (MRSA): burden of disease and control challenges in Europe. Euro Surveill 2010;15:19688. Https://doi.org/10.2807/ese.15.41.19688-en

[9] Vanderhaeghen W, Hermans K, Haesebrouck F, Butaye P. Methicillinresistant Staphylococcus aureus (MRSA) in food production animals. Epidemiol Infect 2010;138:606-25. Https://doi.org/10.1017/S0950268809991567

[10] Lim S-K, Nam H-M, Jang G-C, Lee H-S, Jung S-C, Kim T-S. Transmission and persistence of methicillin-resistant Staphylococcus aureus in milk, environment, and workers in dairy cattle farms. ISfoodborne Pathog $D$ 2013;10:731-6. Https://doi.org/10.1089/fpd.2012.1436

[11]Chuang Y-Y, Huang Y-C. Livestock-associated meticillin-resistant Staphylococcus aureus in Asia: an emerging issue? Int J Antimicrob Agents.

2015;45:334-40.

Https://doi.org/10.1016/j.jijantimicag.2014.12.007

[12]Smyth R, Kahlmeter G. Mannitol salt agar-cefoxitin combination as a screening medium for methicillin-resistant Staphylococcus aureus. J Clin Microbiol 2005;43:3797-9. Https://doi.org/10.1128/JCM.43.8.37973799.2005

[13]Mohammed MA, Sallam KI, Eldaly EAZ, ahdyam, Tamura T. Occurrence, serotypes and virulence genes of non-0157 Shiga toxin-producing Escherichia coli in fresh beef, ground beef, and beef burger. Food control 2014;37:182-7. Https://doi.org/10.1016/j.foodcont.2013.09.035

[14]Sallam KI, Abd-Elghany SM, Elhadidy M, Tamura T. Molecular characterization and antimicrobial resistance profile of methicillinresistant Staphylococcus aureus in retail chicken. J Food Prot 2015;78:1879-84. Https://doi.org/10.1016/j.foodcont.2013.09.035

[15]Clinical, Institute LS. Performance standards for antimicrobial susceptibility testing. CLSI.Wayne, PA; 2017.

[16]El-Gohary AH, El-Gohary FA, Elsayed MM, elfateh M. In-Vitro Investigation on the Antiseptic Efficacy of Commonly Used Disinfectants in Dairy Farms Against Methicillin-Resistant Staphylococcus Aureus. Alex J Vet Sci. 2019;60. Https://doi.org/10.5455/ajvs.14168

[17]Algammal AM, Enany ME, El-Tarabili RM, Ghobashy MO, Helmy YA. Prevalence, antimicrobial resistance profiles, virulence and enterotoxindeterminant genes of MRSA isolated from subclinical bovinemastitis samples in Egypt. Pathogens. 2020;9:362. Https://doi.org/10.3390/pathogens9050362

[18]Lee JH. Methicillin (oxacillin)-resistant Staphylococcus aureus strains isolated from major food animals and their potential transmission to humans. Appl. Environ. Microbiol.2003;69:64.94-89. Https://doi.org/10.1128/AEM.69.11.6489-6494.2003

[19]Huber H, Koller S, Giezendanner N, Stephan R, Zweifel C. Prevalence and characteristics of meticillin-resistant Staphylococcus aureus in humans in contact with farm animals, in livestock, and in food of animal origin,
Switzerland, 2009. Euro Surveill 2010;15:19542. Https://doi.org/10.2807/ese.15.16.19542-en

[20]El-Gohary A, Mohamed, A., Gwida, M. And EL- Mahmoudy, S. Occurrence and Molecular Characterization of Staphylococcus aureus Isolated from Smallholders Dairy Farms and Their Owners. Mansoura Vet Med J. 2016; 17: 1-17. Https://doi.org/10.35943/MVMJ.2016.184763

[21]Kotb S, Sayed M. Sensitivity of methicillin-resistance and methicillinsusceptible Staphylococcus aureus strains to some different disinfectants. Int J Livest Res 2015;5:45-58. Https://doi.org/10.5455/ijlr.20150822031340

[22]Elhaig MM, Selim A. Molecular and bacteriological investigation of subclinical mastitis caused by Staphylococcus aureus and Streptococcus agalactiae in domestic bovids from Ismailia, Egypt. TROP ANIM HEALTH PRO. 2015;47:271-6. Https://doi.org/10.1007/s11250-014-0715-1

[23]Suelam II, Raslan AR, Mohamed ME .Isolation of Staphylococcus aureus from Milk and Human with Reference to its Survival on Surfaces. WJDFS 2012;7:142-5.

[24]Khalifa NO, Elhofy Fl, Fahmy HA, Barakat A. Epidemiological and genetic studies of enterotoxigenic Staphylococcus aureus isolated from goat and human. Am J Infect Dis 2015;3:32-7.

[25]Adwan G, Isayed H. Prevalence and characterization of Staphylococcus aureus isolated from bulk tank milk dairy cow farms in West BankPalestine. Int J Microbiol Res 2018:1-13. Https://doi.org/10.9734/MRJI/2018/40074

[26]Kamal RM, Bayoumi MA, Abd El Aal SF. MRSA detection in raw milk, some dairy products and hands of dairy workers in Egypt, a mini-survey. Food Control 2013;33:49-53. Https://doi.org/10.1016/j.foodcont.2013.02.017

[27] Gwida M, EL-Gohary F. Zoonoticbacterial Pathogens Isolated from Raw milk with Special Reference to. E coli. 2013:2.

[28]Ismail SA, Fadel, H. M. And Mostafa. Staphylococcus aureus and methicillin-resistant Staphylococcus aureus contamination in raw meat products and meat handlers in Port Said city. 4th International Food Safety Conference, University of Sadat City, . 2017:472-89.

[29]Kates A, Thapaliya D, Smith T, Chorazy ML. Prevalence and molecular characterization of Staphylococcus aureus from human stool samples. Antimicrob Resist Infect Control 2018;7:1-9. Https://doi.org/10.1186/s13756-018-0331-3

[30]El-Jakee J, Atta NS, Samy A, Bakry M, Elgabry E, Kandil MM, et al. Antimicrobial resistance in clinical isolates of Staphylococcus aureus from bovine and human sources in Egypt. Glob Vet 2011;7:581-6.

[31] Al-Ashmawy MA, Sallam KI, Abd-Elghany SM, Elhadidy M, Tamura T. Prevalence, molecular characterization, and antimicrobial susceptibility of methicillin-resistant Staphylococcus aureus isolated from milk and dairy products. Foodborne Pathog Dis.62-13:156;2016. https://doi.org/10.1089/fpd.2015.2038 